tion, and it was curable,* indeed, its termination was more favourable than that of melancholia. It sometimes passed into mania. It corresponded with Rush's amenomania, $\dagger$ and to the modern simple mania accompanied by hilarity.

\title{
CLINICAL NOTES AND CASES.
}

The Life History of a Malingering Criminal. By JAMGS Murray, M.B., Assistant Medical Officer, H.M. Prison, Wakefield.

It is a truism that to detect disease is in many instances more difficult than to cure it. In general practice how often do obscure subjective symptoms in a patient puzzle the diagnostic acumen of the rnost experienced of our clinicians, and how often does the post-mortem table prove that "to err is human" in matters medical!

In no branch of medical practice is it more necessary to reason out one's conclusions than in the prison medical service, as nowhere does the fact of illness existing have so important a bearing on the treatment of the individual. The medical officer has a double duty to perform in his official capacity, and has to keep an open unbiassed mind on his daily rounds, and on each separate case, so that on the one hand a "skulker" may not by his means escape his due punishment by feigning disease, and on the other hand that proper medical care and treatment may be granted to those who are really ill and require medical attention.

It does not require very much prison experience on the part of a criminal to find out how important an influence on his welfare the medical officer exercises during his period of incarceration, and what powers of conferring increased comforts the law places in his hands, and many consequently are the devices met with to accomplish those ends. With the help of stethoscope, thermometer, and weighing machine, most of these applications, however, are determined at their true value.

One cannot, however, be too careful before arriving at a complete diagnosis of malingering. Ogston in his "Jurisprudence" says "Serious diseases are known to exist in a latent form with little or no manifestation during life, and are only

* Op. cit., Vol. ii., p. 31.

† See Buckuill and Tuke, p. 234. 
to be detected on inspection after death. A person thus labouring under disease in this form might readily be treated as an impostor." Also there is present in most cases of determined continued malingering some defective mental or bodily condition, which may, or may not, have a direct bearing on the disease feigned. The malingerer is usually a confirmed criminal-in itself evidence of depraved moral tendency-is often distinctly neurotic and exhibits a patience and cunning truly remarkable, and often of his own initiative endures discomforts and deprivations with great nonchalance satisfied if only he at last attains his desired result.

Of the diseases most favoured by the schemer a marked preference is shown - presumably from an indefinite notion of their difficulty of detection-to mental and nervous diseases generally, and of these in particular to epilepsy and paralysis.

Many cases require prolonged careful observation, and though occasionally the medical detective is outwitted, yet as a rule his superior education, ingenuity, and knowledge of disease enable him to circumvent the schemer.

The following is a case of considerable interest in many of its aspects, as the man, whose history is given, was observed by many medical men, trained by long prison experience in the detection of schemers, who almost unanimously designated him a "confirmed malingerer." I have also been able to obtain a fairly complete family history, and account of his general conduct and habits of life while at liberty, and thereby to complement his medical history while in prison.

W. H. T., ætat 43, was committed to this prison on November 2nd, of last year, to await his trial at Assizes on the charge of larceny of ducks. The policeman who brought him said that he had had a " fit" while in the train, but had ralked from the station to the prison without complaint. Immediately after reception to the prison he had another " fit," described by a warder as consisting of his throwing himself over from side to side, considerable drawing of head to right side, and firm clenching of the hands. No epileptic cry, foaming at the mouth, nor markedly heavy breathing after " fit." He was carried into the reception room of the prison, and $\mathrm{Mr}$. Clarke, the medical officer, who was on duty at the time, was sent for. He found him lying on the floor, with eyes closed-no marked stertor, conjunctivæ sensitive to the touch, and pupils to light; distinct resistance to raising eyelid was felt. He answered no questions, and limbs, on being raised, fell powerless and limp. He was sent to Hospital for further observation. From the above date till November 11th his condition was as follows : He lies on his right side on a mattress, placed on the floor. He has milk and beef-tea, which 
he swallows readily from a feeding-cup. He has had on an average five or six "convulsive" attacks daily; the description of those with him tallies with that given above. The fits occur chiefly at night. He has not spoken to the nurses or warders since reception. He lies almost motionless, but follows with his ejes the motions of the officials who enter the room. When asked to move arm or leg or to obtrude tongue he shows no attempt to do so. Sensibility in extremities seems well under his control or dulled, as it requires fairly deep prick with pin to cause any contraction. Reflexes are present. Pupils are sensitive to light and reflexly, and conjunctivæ sensitive. When desirous to micturate or defæcate, he moans and makes inarticulate sounds to the nurses.

In discussing the case in his presence, marked surprise was expressed at the absence of frothing at the mouth and of expulsion of the contents of the bladder during his violent convulsive attacks, and special attention on the part of those with him was directed to these points. The result was that on our next visit we were told that the following fits had been accompanied by both those symptoms, although previously neither had been present.

The whole history of the case pointed to but one conclusion-that the man was feigning epilepsy and paralysis-and he was accordingly put in a separate cell in Hospital, on the 11th. Up to that date no previous history had been obtained, nor had we recognized him as a former prisoner. On the following day he was recognized by one of the officials as having been in custody before, and several facts were brought to our notice which were strongly confirmatory of the diagnosis formed. The strongest proof of any, however, as to his having retained the perfect use of his limbs was aftorded by his selfdestruction, the modus operandi of which was as follows : On the evening of the 14th, in the interval between two visits by a warder, he was able to rise from his bed, tear his bed-clothes, and join thestrips together, place his cell-stool under the window, rise on it and step from thence to the window-ledge, balance himself on it (about three inches broad) while he opened a ventilating pane of glass in the upper half of the window, and tied his rope to the bars outside; and finally after making a noose in the free end of his rope and inserting his head in it, to kick his stool clear. He was found hanging thus on the warder's next visit, and though immediately cut down and restoratives applied, was found to be quite dead.

The above was his history when last detained in this prison. Inquiries which had been set on foot in regard to him while under observation revealed a considerable part of his previous history, which is interesting and instructive.

The clergyman of his native parish, in answer to a communication on the subject kindly sent by my friend and colleague, the Kev. Aspinall Addison, wrote as follows: "He was notorious for his pilfering habits ... but he had been brought up to steal from child- 
hood by a most dishonest mother, so that I think he had hardly any ides, but the very faintest, that stealing was morally wrong. Moreover, I believe that he had incipient insanity, and the man's cunning confirms this impression. His mother, I am told, was affected in the same way. He had no brother or sister. Of his father I have no information. He was always perfectly civil and obliging to me, and very willing to do a kindness. His habits and conduct were eccentric. $\mathrm{He}$ did a little work, but only a little, and it would have been wonderful how he managed to make a living had not the explanation been 80 obvious."

The police superintendent of the district was applied to in regard to his assumed epileptic tendency, and answered: "I have made inquiry as to whether he was known to be subject to fits in his native district. I cannot find that he has ever had a fit in reality, but it was no nncommon thing for him to throw himself down and lie for a long time to make people believe that he was unconscious. This was generally done when he was in trouble. When in custody here on a previous occasion he said he was very bad with heart disease. When last in custody this complaint had left him, but he said he had had several fits during the night. I did not, however, see him in any of them."

The most important communication I received, however, was one kindly sent me by the Medical Officer of the district in which he lived, and was as follows : " $\mathrm{He}$ was in the habit of frequently stopping me and asking me to prescribe for rheumatic pains in back, pleurodynia, or pruritus. I never saw him in a fit. About midnight one day I received a letter from the overseer of the parish saying that $T$. had been attacked by a neighbour, and had received severe injuries as he was unconscious. On arriving I noticed that he had received a conple of black eyes and was laid on the floor feigning unconsciousness. Conjunctive and pupils were sensitive, but he would not answer when spoken to. I told the overseer that he was shamming, and that he had better be removed to the Workhouse next morning. This was accordingly done, but not without strong protest and opposition on the part of the man, who threatened to take a summons out against the overseer. The same day he discharged himself from the Workhouse, and walked home, a distance of three miles. He was an illegitimate child. His mother was a most untruthful woman, and was addicted to petty pilfering. His father was a member of a very neurotic family. His paternal aunt committed suicide, a sister a deaf mute, and a brother was confined in an asylum. There is no family history of epilepsy or phthisis."

The above three notes throw a strong light on his history while at large, on his habits, domestic relations and hereditary tendencies. His father's relations show a distinct tendency to mental defects, his mother is a petty criminal, and of generally loose morality. He is born and bred under depraving influences, and at an early age he drifts into crime, and I find him in 1863 - being then 17 jears of agehaving his first conviction recorded. 
The following is his criminal record from that time till the date of his death :-

Date.

Charge.

Feb. 23, 1863 Fowl stealing

Mar. 14, 1864 Ditto

Jan. 6, 1866

April 28, 1868

Nov. 3, 1869

Mar. 22, 1881

Sept. 28, 1883

Jan. 18, 1887

Nov. 2, 1889
Stealing wearing apparel

Damaging apple trees

Stealing quicklime Attempted bestiality Larceny noteworthy occurred during that period.

On his second conviction he did not behave well and had as many as twelve reports rendered against him for misconduct on different occasions, chiefly for idleness and laziness. There is no note of his having made any complaint as to his health up till this time.

His next sentence is one of twelve months' hard labour, and he is reported on as follows by the Medical Officer: "He was sent to prison on December 19th, 1865, to await his trial at Sheffield Sessions. On December 30th, he was admitted to hospital for wound of the scrotum, supposed to have been done (as he said) by accident with the night pot in his cell. On the 6th of January he was taken to Sheffield and committed for twelve months. On January 26th, he was discharged from hospital - the wound being perfectly healed-and in the evening of the same day was admitted again, having re-opened the wound with his fingers. On March 21 st he was again discharged from hospital, the wound again having healed, and in the evening of the same day he again re-opened it. He was ordered to be kept in his cell under restraint and continued there till the 25 th, when he was again sent to hospital and remained there till April 16th. He was then discharged, and ordered to have his usual exercise, but to have the cuffs on while in his cell. In the evening of the same day he was found by one of the officers attempting to re-open the wound with a table in his cell, and had again to be sent to the hospital. Again he was discharged from hospital on July 10th, only to be readmitted on the 12th for the same reason." He continued in hospital until October 25th, when he was finally discharged and remained at ordinary labour till the date of his discharge from prison, January 3rd, 1867. The Medical Officer's opinion of him is summed up in the following note on the expiration of his sentence: "In the early part of this man's imprisonment he was a perfect nuisance. Latterly, he has conducted himself better, and has shown that he is capable of behaving himself properly, and therefore ought to be punished when he misconducts himself."

He is next sent to prison in April, 1868, on a sentence of six 
weeks' imprisonment. On reception, he complains of diseased lungs and cough, and is sent to hospital for examination and observation. Here he remains during this whole period, but on discharge the Medical Officer considers him " healthy " and " a thorough humbug."

In November, 1869 , he is again committed to prison and sentenced to penal servitude for seven years. The first few months of the sentence are spent in Wakefield, and on removal to a Convict Prison, the following note is sent with him: "He has been exceedingly troublesome while here, and has on several occasions cut and injured himself in order to be sent to hospital. When not in hospital he has frequently sent for the surgeon in the night, and at otber irregular hours." The same course of conduct seems to have been sustained in the different convict establishments to which he is sent. In each he found his way into hospital, where he remained for varying periods-the diseases affected being many-from "bruise" to " epilepsy," but being chiefly described in the medical reports as "anomalous," "observation," and "malingering." On the other hand, the following note by one of the Medical Officers explains itself. March 2nd, 1871 : "At this time a confirmed and very cunning malingerer; was cured by corporal punishment. Has latterly behaved very well." He was eventually discharged in good physical condition on the expiration of his sentence.

He does not again appear in the prison records until September, 1883, when he is sent to $W$ akefield Prison to await his trial at the Assizes. Immediately on reception be is taken ill, and is at once seen by. the assistant-surgeon, who notes that " he sat in a box and seemed at his last gasp. His head was lying back, and there was a streak of blood from his mouth back to his right ear. He gasped a few words and said that he had been kicked on the testicles by the policemen. No marks of "kick" ; pulse good, but quick; skin cool, and body well nourished. He was, however, sent to hospital for observation, and remained there while waiting his trial, but did not return to prison, as he was acquitted of the charge. The note on discharge was " a confirmed malingerer."

His next committal to prison is in January, 1887. On reception, he complained of "fits" and general pains, and next day sent urgently for the surgeon, complaining of intense abdominal pain and inability to micturate. He also stated that he had injured his scrotum three weeks ago, and showed the scar of the self-inflicted wound of 1865 as the result of that injury, also stating that since then (three weeks ago) he had suffered from difficulty of micturition and hæmaturia. He was sent again to hospital for observation, and remained there during the rest of his imprisonment. On discharge, the note is: "Has felt better each day as his term of imprisonment expires." On this occasion he did not confine himself to urinary symptoms, but was "very hypochondriacal and always grumbling." On his urine being found normal, he transferred his suffering to the 
stomach and upper part of the abdomen. Nothing definite, however, was detected in his case, and he was undoubtedly again malingering.

This completes his history, as he did not again come under notice until November, 1889, when, as related above, he committed suicide. Out of a total imprisonment of (excluding his first two sentences, when he had evidently not learned to malinger) eight years and 107 days, he spent four years and 114 days in hospital. In the various prisons in which he was located he must have come under the notice of from twelve to twenty medical men, all with special experience in the detection of feigned diseases, and although to many of these he was known as a confirmed malingerer, yet he was evidently treated on the assumption that actual disease might have been present, and retained in hospital under observation until all reasonable doubt was dispelled. The only temporary cure for his disease seems to have been the flogging which he received; there is no record of his having been admitted to hospital for a period of 18 months after this event-the longest time, by far, in his prison history during which he performed ordinary prison labour. During all his prison life his general physical condition seems to have been good, his weight varying from 140 to $152 \mathrm{lbs}$; ; only on one occasion does he seem to have lost weight, and then only for a few weeks. His mental condition seems to have been questioned only on one occasion-during his period of penal servitude-when he is reported as "weakminded and under observation." This, however, seems to have been very temporary; no delusions are ever noted as being present, and he is soon transferred to ordinary penal conditions.

As a psychological study this man's case is very interesting and important. His hereditary acquirements are unsound, mentally and morally. Himself the product of a neurotic father, and a most immoral mother, his domestic surroundings and upbringing do not conduce to correct his congenital tendencies, and he naturally grows up criminal and anti-social, idle and vicious. From the beginning of his prison-life he shows marked disinclination to settled labour or restraint of any kind, and finding that the only means of escaping his irksome duties is by personal defect, he mutilates himself and continues to do so whenever occasion requires. As he grows older and associates more with fellow-criminals he finds that less violent measures are quite as effective, and during the whole of the rest of his prison life-and in civil life when in troublo-he is full of complaints and illnesses. 
That a "Mens sana in corpore sano" would continue for such a long period of time to attempt deception is improbable; ordinary experience among prisoners teaches otherwise. A flogging would have cured such, effectually and for ever, but in his case it had only a temporary effect. There is no evidence, at any time, of any definite delusion or hallucination, unless we assume the disordered subjective feelings to bedue to intellectual disorder. His self-destruction is of some importance; no adequate cause can be offered for his suicide, unless the fear of another long period of penal servitude acting on a weakened mind created a sudden impulse which was carried into effect immediately.

Whether we believe in moral insanity, as distinguished from intellectual, or not, we must at leas acknowledge that in this man's case all the elements of moral instability and depravity were well represented. To quote Maudsley in a recent number of this Journal,* he was " an essential or natural criminal-a criminal by reason of defective mental organization," "a specially manufactured article of an anti-moral and anti-social type-sprung from : a family in which insanity existed;" "an instinctive criminal because the gratification of his urgent and absorbing self-regarding instincts was not, and could not, be checked by any sense of duty to others of which he was congenitally destitute, and constitutionally incapable." If we add to this a considerable amount of low cunning and dogged persistence in striving to avoid legally-imposed labour, we are enabled to distinguish the mental conditions under which he became a confirmed criminal and a successful malingerer.

Case of Homorrhage into Pons Varolii. By James RoRIe, Mi.D., Medical Superintendent, Royal Assylum, Dundee.

J. W. ; female ; øt. 25 ; single ; domestic servant; Protestant ; admitted from parish of Liff and Beuvie on 25th April, 1886.

Dementia.-Patient has been insane for $4 \frac{1}{2}$ years. Her sister stated that the illness came on quite suddenly without any assignable cause. Was at first very confused, then became violent and ontrageous, and had to be kept tied in bed. Has been so for $4 \frac{1}{2}$ years. Has of late become much stronger physically, and was sent to asylum becanse her relatives were afraid they would be unable to keep her in bed if she got much stronger. Menstruated very severely before occurrence of her illness. Menses returned several times, but has been altogether absent for two or three years.

$$
\text { * “ Journal of Mental Science," July, } 1888 .
$$

